\title{
PERANAN TENAGA PEMASARAN DALAM MENCARI PANGSA PASAR UNTUK MEMPERLUAS DAERAH PADA DANAMON SIMPAN PINJAM
}

\author{
Dewi Budhiartini, SE,M.Si,PhD \\ Universitas Amir Hamzah \\ Budhidewi12@gmail.com
}

\begin{abstract}
Abstrak
Fokus perbankan yang universal, diimplementasikan pada tahun 2003 menentukan arah ekspansi bisnis Danamon kedepan. Pada akhir 2004, Danamon telah melengkapi rangkaian segmen usahanya, mulai dari mass market, perbankan komersial dan UKM, perbankan ritel, bisnis kartu kredit, perbankan syariah, perbankan koperasi,pasar modal dan lembaga keuangan, serta Adira Finance Adapun yang menjadi rumusan masalah adalah: "seberapa besar peranan tenaga pemasaran dalam mencari pangsa pasar dalam memperluas daerah pemasaran di Danamon Simpan Pinjam”. Tenaga pejualan merupakan ujung tombak mata rantai dan ratusan ribu produsen skala kecil., menengah dan besar disetiap negara didunia ini.Peranan tenaga pemasaran dalam pencapaian tujuan dan sasaran perusahaan dapat dilihat dalam pencapaian keuntungan usaha perusahaan. Keberhasilan pencapaian tujuan yang telah direncanakan dan harga penjualan yang telah direncanakan dan harga penjualan yang telah ditentukan.Hasil penelitian ini menyatakan baahwa Tenaga pemasaran ternyata merupakan metode promosi yang lebih baik dibandingkan dengan cara promosi lainnya jika perusahaan harus senantiasa berhubungan dengan pelangganya dan memelihara hubungan dengan pelanggan. penyediaan tenaga pemasaran yang handal dan dapat bertahan lama pada perusahaan dalam upaya untuk terus meningkatkan penjualan.
\end{abstract}

Keyword: Tenaga Pemasaran, Pangsa Pasar. 


\section{PENDAHULUAN}

Pemasaran bermula dari kenyataan manusia adalah mahluk yang memiliki kebutuhan dan keinginan. Karena beberapa produk dapat memuaskan kebutuhan tersebut, maka pemilihan atas produk dituntut oleh konsep nilai dan kepuasan yang diharapkan. Sebagian besar masyarakat bekerja atas dasar prinsip pertukaran yang berarti seseorang mengkhususkan diri dalam memproduksi produk tersebut dan mempertukarkan untuk memenuhi kebutuhannya.Pemasaran mencakup semua kegiatan yang berkaitan dengan pasar yakni mencoba untuk mewujudkan pertukaran potensial. Kegiatan pemasaran berkaitan dengan upaya-upaya untuk menciptakan, merangsang dan memenuhi permintaan yang didasarkan atas kebutuhan dan keinginan konsumen.Pemasaran mencakup usaha peruasahaan yang dimulai dengan mengindentifisir kebutuhan konsumen yang perlu dipuaskan, menentukan produk yang diproduksi, menentukan harga pokok produk yang sesuai, menetukan cara-cara promosi dan pengaturan/penyewaan produk tersebut.Jadi kegiatan pemasaran adalah kegiatan yang saling berhubungan dengan sistem. Dengan mengetahui kedudukan produk dalam suatu pasar, maka perusahaan dapat menentukan langkah-langkah kebijaksanaan pemasaran yang tepat dan untuk memperluas pangsa pasar yang ada, suatu perusahaan tidak boleh beranggapan bahwa kenaikan pangsa pasar dalam pasar yang mereka layani secara otomatis akan memperbaiki tingkat pendapatan laba mereka. Hal ini tergantung pada strategi mereka dalam meningkatkan pangsa pasar mereka, mungkin jauh melebihi nilai atau tingkat pendapatan mereka.

\section{KAJIAN PUSTAKA}

Menurut Kotler ( 2000 : 10) : " Pemasaran Adalah suatu proses social dan manajerial yang di dalamnya individu dan kelompok mendapatkan apa yang mereka butuhkan dan inignkan dengan menciptakan, menawarkan dan mempertukarkan produk yang bernilai dengan pihak lain “. Jadi dapatlah di simpulkan bahwa istilah pemasaran bukan hanya pemenuhan permintaan dan penetapan harga atau penjualan dan pendistribusian barang kepada konsumen tetapi meliputi kegiatan pelayanan kepada konsumen setelah menerima barang yang diproduksikan. Menurut Irawan (2000 : 25) : “Pangsa pasar adalah bagian dari keseluruhan permintaan suatu barang yang mencerminkan golongan konsumen menurut ciri khasnya, seperti tingkat pendapatan, umur, jenis kelamin, pendidikan dan status sosial ". Dari defenisi-defenisi diatas, maka dapat disimpulkan pangsa pasar adalah besarnya bagian pasar yang dikuasai oleh suatu 
perusahaan. Dengan kata lain penguasaan suatu produk terhadap pasar atau besarnya jumlah produk yang diminta yang dihasilkan oleh suatu perusahaan dibandingkan degan jumlah permintaan di pasar. Pangsa pasar ini dapat dipecahpecah menurut wilayah politis, kawasan geografis yang lebih besar, ukuran, pelanggan, tipe pelanggan, dan teknologinya. Dalam memasarkan produk, tenaga pemasaran mempunyai peranan yang penting dalam masyarakat karena pemasaran menyangkut berbagai aspek kehidupan, termasuk bidang ekonomi dan sosial.Karena kegiatan pemasaran menyangkut masalah mengalirnya produk dari produsen ke konsumen, maka pemasaran menciptakan lapangan kerja yang penting bagi masyarakat.Di samping itu, perlu disadari bahwa sebagian besar pengetahuan uang masyarakat konsumen mengalir ke kegiatan pemasaran.

Pentingnya pemasaran dalam masayarakat, tercermin pula pada setiap kehidupan dalam masyarakat yang tidak terlepas dari kegiatan pemasaran.Media advertensi yang dipergunakan untuk mempresentasikan produk, toko tempat kita berbelanja dan banyak lagi kegiatan, merupakan kegiatan pemasaran.Selain itu, pemasaran selalu mendorong untuk dilakukannya penelitan dan inovasi, sehingga menimbulkan terdapatnya produk-produk baru.Hal ini karena pemasaran selalu berusaha menggugah dan menarik para konsumen, yang kegiatan ini membutuhkan tenaga pemasaran tenaga kerja yang cukup banyak.

Keberhasilan suatu perusahaan mencapai tujuan dan sasaran perusahaan sangat diprngaruhi oleh kemampuan perusahaan memasarkan produknya.Tujuan perusahaan untuk dapat menjamin kelangsungan hidupnya berkembang dan mampu bersaing hanya mungkin apabila perusahaan dapat menjual produknya dengan harga yang menguntungkan pada tingkat kuantitas yang diharapkan serta mampu mengatasi tantangan dari pesaing dalam pemasaran.Oleh katena itu, para pimpinan bidang pemasaran dihadapkan pada usaha untuk mencari kesempatan atau peluang tersebut bagi pencapaian tujaun perusahaan nya dapat berhasil. Di dalam proses hehidupan suatu perusahaan, pemasaran merupakan salah satu fungsi di samping fungsi lain.

\section{METODE PENELITIAN}

\section{Pendekatan Penelitian}

Dalam menyusun skripsi ini diperlukan adanya sejumlah data yang berhubungan dengan masalah yang dibahas, dengan menggunakan 2 (dua) Jenis penelitian :

1. Penelitian Kepustakaan (Library Research)

2. Penelitain Lapangan (Field Research) 


\section{Penelitan Kepustakaan (Library Research)}

Library Research adalah penelitian yang dilakukan berdasarkan teori-teori pada buku-buku literatur dan bahan-bahan ilmiah lainnya yang memuat tentang masalah-masalah penelitian yang penulis anggap penting.

2. Penelitian Lapangan (Field Research)

Field Research adalah penelitian yang dilakukan secara langsung kelapangan dengan mengadakan wawancara langsung kepada pihak-pihak yang berhubungan dengan pokok pembahasan untuk memperoleh keterangan dan data yang diperlukan.

\section{Teknik Pengumpulan Data}

Dalam rangka penelitian skripsi ini, penulis melakukan dua cara teknik pengumpulan data penelitian yaitu :

1. Observasi (Pengamatan), yaitu melihat secara langsung dan sepintas peranan tenaga pemasaran dalam mencari pangsa pasar di perusahaan yang diteliti.

2. Wawancara, yaitu mengadakan tanya jawab dengan pihak perusahaan yang berwewenang memberikan keterangan yang diperlukan.

\section{Teknik Analisa Data}

Metode analisa dalam penelitian ini terdiri dari :

1. Metode Deskriptif

Yaitu analisis yang dilakukan dengan mengumpulkan data, menyusun dan menafsirkan serta menganalisa sehingga memberikan gambaran mengenai peranan-peranan tenaga pemasaran dalam mencari pangsa pasar untuk memperluas daerah pemasaran.

2. Metode Deduktif

Yaitu mengambil kesimpulan khusus berdasarkan teori yang telah diterima sebagai suatu kebenaran umum mengenai fakta yang diamati.

Dari kedua metode ini dapat disimpulkan bahwa sangat besar peranan tenaga pemasaran dalam mencari pangsa pasar.

\section{DISCUSSION}

\section{Peranan Tenaga Pemasaran Dalam Mencari Pangsa Pasar}

Tenaga pemasaran merupakan jabatan yang menjanjikan, terutama bagi para tenaga pemasaran muda dan karyawan pemula yang berbakat dan ingin maju dalam karier pekerjaannya. Peranan mereka dalam menunjang keberhasilan operasi perusahaan nampak jelas sekali, yaitu menjualkan produk yang dimiliki oleh perusahaan. Tenaga pemasaran merupakan ujung tombak mata rantai kegiatan distribusi penjualan yang dihasilkan. Adapun tugas utama tenaga pemasaran yang dimiliki Danamon Simpan Pinjam Marelan Medan adalah 
mencari pelanggan baru yang berpotensial, menjaga hubungan baik dengan pelanggan yang ada, melakukan survey pemasaran dengan analisis pinjaman dan mengunjungi calon peminjam. Secara umum kita dapat membayangkan peranan yang diberikan seorang tenaga pemasaran bagi perusahaan. Peranan tersebut sudah pasti membantu memasarkan produk yang dimiliki oleh perusahaan.Dalam bentuk yang lebih khusus peranan tersebut juga dapat berupa pengenalan produk perbankan kepada nasabah baru, atau menjadi seorang konsultan kepada nasabah baru atau calon nasabah mengenai produk pinjaman. Peranan yang diberikan oleh tenaga pemasaran adalah mencari konsumern baru, menjual, melayani dan mengumpulkan informasi. Perusahaan harus memutuskan pasti relatif kepentingan berbagai macam peranan dari pada tenaga pemasaran tersebut. di lain pihak, pelobbi cenderung memfokuskan komunikasi, pelayanan, dan pengumpulan informasi. Setiap perusahaan pada umum nya meminta tenaga pemasarannya menetapkan sasaran tertentu dari setiap aktivitasnya sehingga kinerja mereka terhadap sasaran dapat diukur.

\section{Masalah hambatan yang dihadapi oleh perusahaan dalam mencapai target penjualan dan usaha-usaha pemecahannya.}

1. Proses perekrutan dan seleksi tenaga pemasaran

Sumber perekrutan tenaga pemasaran melalui media online dan koran dengan menjanjikan tenaga pemasaran dekat dengan kantor tidak terealisasi dan proses seleksi yang ketat dan selektif hendaknya menjadikan para tenaga pemasaran lebih agresif dalam menjual produknya. Akan tetapi perusahaan tidak memperoleh tenaga penjual yang berkualitas dan memiliki latar belakang serta pengalaman yang memadai untuk mendukung dalam mencapai target penjualan.

Untuk mengatasi masalah tersebut sebaiknya dimasa mendatang perusahaan merekrut tenaga pemasaran yang sudah berpengalaman dan terampil.

2. Motivasi dan Kompensasi tenaga penjualan

Sistem insentif atau kompensasi yang diberikan perusahaan selama ini sangat kurang sekali, karena membuat tenaga pemasaran kurang termotivasi dengan sistem ini. Apalagi tunjangan transport yang diberikan kepada tenaga pemasaran sebesar Rp. 200.000,- akan terealisasi apabila tenaga pemasaran mencapai Rp. 100.000.000,- dan itu hanya akan diberikan sebesar Rp. 100.000.000,- untuk mendapatkan keseluruhan tunjangan transport apabila mencapai lebih dari Rp. 150.000.000,-

3. Perluasan daerah pasar

Tenaga pemasaran mengalami kesulitan dalam menjual disebabkan pansa pasar yang dibatasi oleh perusahaan yaitu hanya radius $10 \mathrm{~km}$ saja. Jadi memberikan dampak hanya nasabah yang sudah ada saja yang bisa dikelola dan nasabah sahabat lam yakni nasabah yang sudah berakhir 
peminjaman kreditnya terhadap perusahaan dan meminjam lagi kepada

Danamon Simpan Pinjam.

Dari penjelasan diatas disebutkan beberapa yang harus diperhatikan pihak perusahaan khususnya dalam penyediaan tenaga pemasaran yang handal dan dapat bertahan lama pada perusahaan dalam upaya untuk terus meningkatkan penjualan. Kelengahan dalam menambah kuantitas dan kualitas tenaga pemasaran lama kelamaan dapat menghancurkan perusahaan dalam jangka panjang dan menurunkan penjualan dalam jangka pendek sehingga membuat perusahaan tersebut bangkrut dan tutup. Dan ini sudah terjadi pada unit Setia Budi dan Belawan.

Untuk mengalami masalah tersebut adalah dengan pemberian insentif dan kompensasi yang sesuai dengan kinerja tenaga pemasaran. Serta diberikan pelatihan lebih dalam praktek langsung dari pada hanya teori saja. Kurangi pemberian jam bekerja hingga malam hari sehingga membuat tenaga pemasaran kelelahan.

\section{KESIMPULAN}

\section{Kesimpulan}

1. Tenaga pemasaran ternyata merupakan metode promosi yang lebih baik dibandingkan dengan cara promosi lainnya jika perusahaan harus senantiasa berhubungan dengan pelangganya dan memelihara hubungan dengan pelanggan. Penggunaan tenaga pemasaran dalam memasarkan produk adaah sangat tepat, karena langsung bisa mengembangkan relasi lebih meluas. Dan akan lebih baik apabila tenaga pemasaran ditambah kuantitas nya.

2. Trend perkembangan tingkat penjualan yang terlihat sama dengan trend perkembangan biaya penjualan menunjukan besarnya pengaruh tenaga pemasaran terhadap peningkatan penjualan produk Danamon Simpan Pinjam.

3. Dengan makin berkembang nya pasar didaerah-daerah perusahaan semakin mudah mendapatkan pangsa pasar baru tetapi dibatasi radius yang diberikan oleh pihak perusahaan sehingga pemasaran juga mengalami kendala dalam mencari nasabah baru.

\section{Saran}

1. Agar Danamon Simpan Pinjam tidak mendapatkan hambatan dalam menjalankan pemasaran, maka sebaiknya untuk mendapatkan tenaga pemasaran yang terampil hendaknya perusahaan mencari calon tenaga pemasaran yang telah berpengalaman dalam pemasaran.

2. Sistem perhitungan insentif yang terlalu sedikit untuk semua tenaga pemasaran. Hendaknya perusahaan ini memberikan perhitungan insentif yang lebih besar untuk tenaga penjualan agar lebih termotivasi dalam mencari nasabah, dengan demikian tenaga penjual lebih dihargai dan sejahtera. 
3. Perusahaan juga perlu untuk menambah tenaga penjual (Acoount Officer) agar bisa lebih memperluas daerah pemasaran.

4. Radius yang dibatasi hingga $10 \mathrm{~km}$ hendaknya diperluas lagi agar tidak membatasi tenaga penjual dalam mencari pangsa pasar.

\section{REFERENCES}

Alma Buchari, Manajemen Pemasaran dan Pemasaran jasa, Cetakan Keempat, Afabeta, Bandung. 2000

Basu Swastha DH \& Ibnu Sukotojo, Pengantar Bisnis Modern, Edisi Ketiga, Cetakan ketiga, Liberty, Yogyakarta, 2000.

Irawan dkk, Pemasaran Prinsip dan Kasus, BPFE-Yogyakarta, Yogyakarta, 2000 .

Idriyo Gitosudarmo, Manajemen Pemasaran, BPFE-Yogyakarta, Yogyakarta, 2000 .

Lamb, Hair dan McDainel, Pemasaran, Salemba Empat, jakarta, 2000.

M. Mursid, Manajemen Pemasaran, takan ketiga, LiBumi Aksara, jakarta, 2003.

Nugroho J. Setiadi, Perilaku konsumen, takan kePertama, Prenada Media Group. Jakarta, 2003.

Sofyan Assauri, Manajemen Pemasaran, Dasar, konsep dan Strategi, Cetakan Ketujuh, PT. Raja Grafindo Persada, Jakarta, 2002.

Siti Khotijah, Smart Strategy of Marketing, CV, Alfabeta, Bandung, 2004.

Sutojo Siswanto, Salesmanship, Keahlian Menjual Barang dan Jasa, Cetakan pertama, Damar Mulia Pustaka, 2000.

Jurnal Insitusi Politeknik Ganesha Medan

Juripol, Volume 4 Nomor 1 Maret 2021 